\title{
当科で経験した食道異物の臨床的検討
}

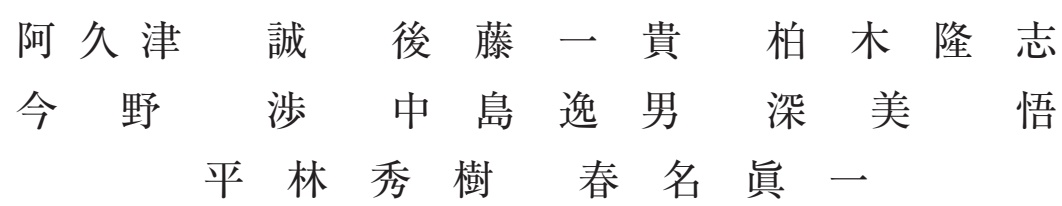

要旨：食道異物は摘出が容易な症例や自然排泄が期待できる症例が多いが, 時として消化管穿孔や皮下・縦隔 気腫などの合併症を引き起こす事がある。今回われわれは過去 11 年間で経験した, 食道異物の症例を若干の 文献的考察を加え報告する。

症例は全 98 例， 10 代と 60 〜 70 代の二峰性分布を認めた。種類別では PTP が最多であった。30 例が入院 加療を要したが軽快退院していた。

一般的な耳鼻咽喉科診察では食道内の異物を見落としてしまう恐れがあり，上部消化管内視鏡検査や頸部 CT 検査は重要である。また鋭的異物の誤飲を積極的に疑う場合, 後に下部消化管穿孔や穿通をきたす恐れが あるため他科との連携を図り，下部消化管精査も検討すべきである。

キーワード：食道異物，PTP，義歯，内視鏡治療，直達鏡下異物摘出術

\section{Summary A clinical examination of esophageal foreign bodies managed by our department:}

Makoto Akutsu, Kazutaka Goto, Takashi Kashiwagi, Wataru Konno, Itsuo Nakajima, Satoru Fukami, Hideki Hirabayashi and Shin-ichi Haruna. Department of Otorhinolaryngology \& Head and Neck Surgery, Dokkyo Medical University

Although many esophageal foreign bodies are easily removed or can be expected to be eliminated naturally, a few lead to complications such as gastrointestinal perforation and subcutaneous or mediastinal emphysema. We discuss the management of cases of esophageal foreign bodies over the last 11 years as a contribution to the literature.

We encountered 98 cases of esophageal foreign bodies during the study period. We observed a bimodal age distribution, with clusters identified at ages 10-19 and 60-70 years. A push-through pack was the most common type of foreign body identified. Thirty patients required hospitalization; however, they were discharged after their condition improved.

Esophageal foreign bodies may be overlooked during routine otolaryngological examinations; therefore, it is important to perform upper gastrointestinal endoscopy or cervical computed tomography in suspected cases. Accidental ingestion of a sharp foreign body may lead to delayed perforation or penetration of the lower digestive tract. When this condition is suspected, interdepartmental coordination is important to perform a careful examination of the lower digestive tract.

Key words: esophageal foreign body, PTP, denture, endoscopic treatment, directoscope-guided foreign body removal 


\section{はじめに}

食道異物は耳鼻咽喉科の日常診療において遭遇す る，比較的稀な疾患である。摘出が容易であった り，胃内落下や自然排泄が期待できる症例がほとん どではあるが，鋭利な異物や大きな異物の場合は消 化管穿孔や皮下気腫などの重篤な合併症を引き起こ す事がある。そのため治療や経過には十分な注意を 要する。今回われわれは, 過去 11 年間で当科を受 診・治療を行った食道異物症例について若干の文献 的考察を加え報告する。

\section{対象}

2006 年 4 月から 2017 年 3 月までの 11 年間に, 食 道異物または食道異物を疑い当科受診・加療を行っ た症例を後方視的に検討した。検討項目は，異物の 種類，摘出方法，合併症などとした。

\section{結果}

11 年間で経験した症例は男性 46 例，女性 52 例 の計 98 例で，年間平均 8.9 件であった。年ごとの 多少のばらつきは認めるが，特に増加・減少などの 一定の傾向は示されなかった。

年齢分布と性別をグラフに示す（図 1)。年齢分布 に関しては, 10 歳未満と $60 \sim 70$ 歳代の 2 峰性で多 く認めた。性別間では大きな差は認めなかったが, 高齢になるにつれ女性の割合が多い傾向があった。

次に各年代に打ける異物の種類の分布を示す (図 2)。Press through package (PTP) が最多の 31 例であった。ついで魚骨，食塊，義歯と続いた。 異物毎の特徵としては, PTP や義歯は高齢層で多

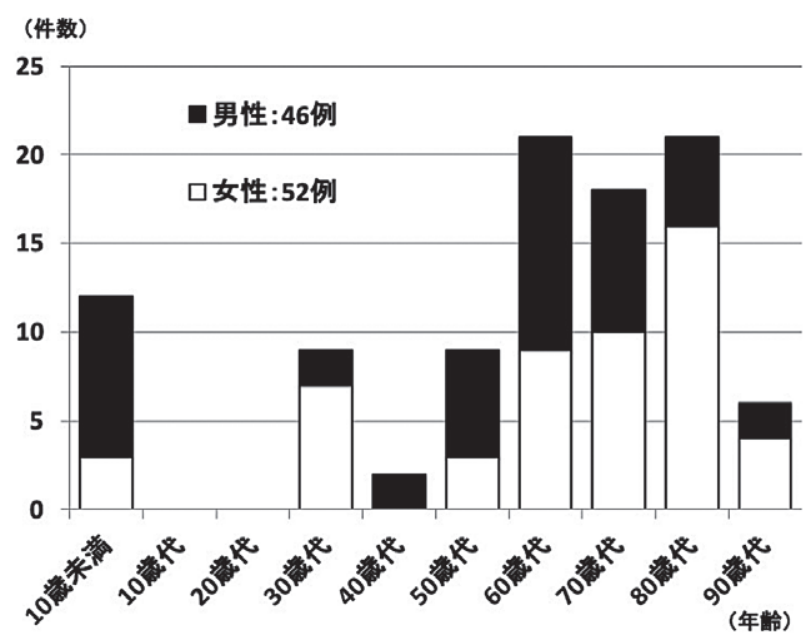

図 1 当科を受診した食道異物症例の年齢分布 10 歳未満の乳幼児, 60 歳〜 80 歳代の高齢層の 2 峰 性に症例を多く認めている。

性別間では有意な差は認めなかった。
く認められ，コインや拈もちゃは小児で多く認めら れた。魚骨・食塊は年齢に関係なく幅広く分布して いた。その他様々な異物がみられたが，歯科治療中 のインレー (いわゆる金歯) の誤飲や，精神発達遅 滞・精神疾患を有する患者による針・ネジなどの誤 飲であった。

異物の種類ごとで分け，まず異物の嵌在部位ごと に分類したものを示す（図 3)。過去の文献と同様, 第一狭窄部（食道入口部）に異物を認める症例が約 7 割と最多であった。以下第二狭窄部，第三狭窄部 と続いていた。画像検査では食道内に異物を認めた ものの，摘出の際には胃内に落下していた症例が数 例みられた。次にそれぞれを摘出方法別に分類した

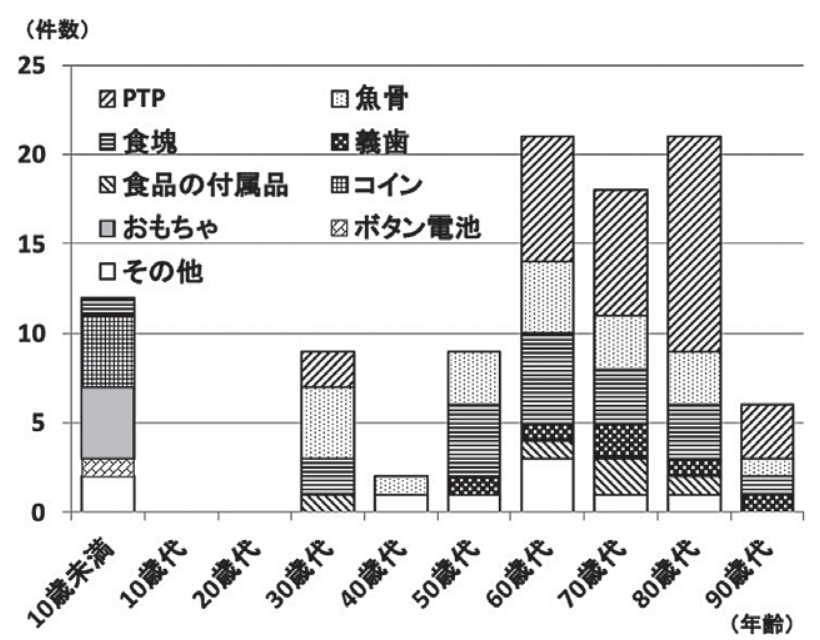

図 2 異物の種類ごとの年齢分布 PTP は最多（31 例）であったが高齢層中心であっ た。小児においてはコインやおもちゃなど，簡単に 手にすることができるものを誤飲するケースが多 かった。

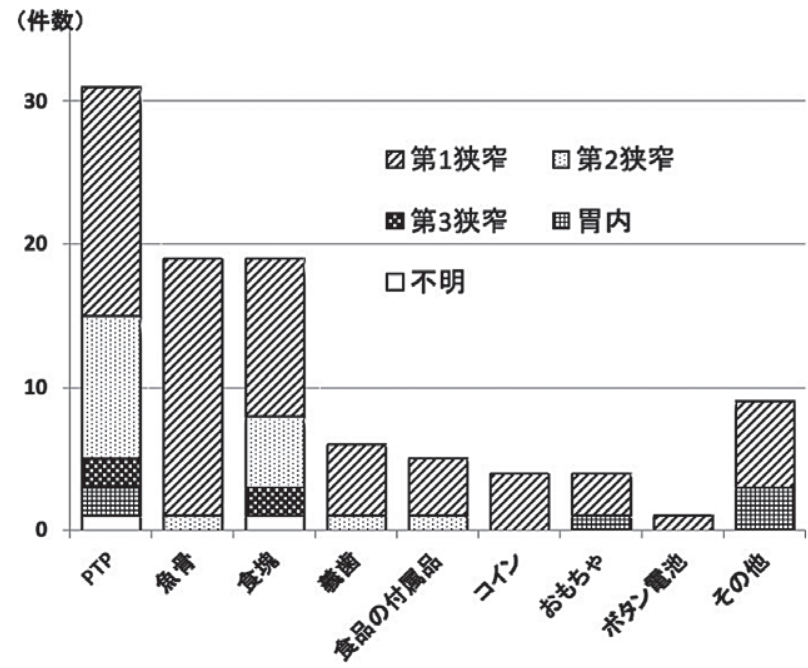

図 3 異物の種類ごと, 嵌在部位による分布 異物の嵌在部位は第 1 狭窄が最多で, 全体の約 7 割 を占める。以下第 2 狭窄, 第 3 狭窄と続く。 
ものを示す（図 4)。当科での異物摘出方法は, 上 部消化管内視鏡を用いた方法と全身麻酔下で食道直 達鏡を用いた方法の 2 つを中心に施行していた。特 にPTPや食塊は上部消化管内視鏡での摘出を，魚 骨は食道直達鏡下での摘出を中心に行っていた。食 塊においては，外来診察時に喉頭内視鏡を食道内に

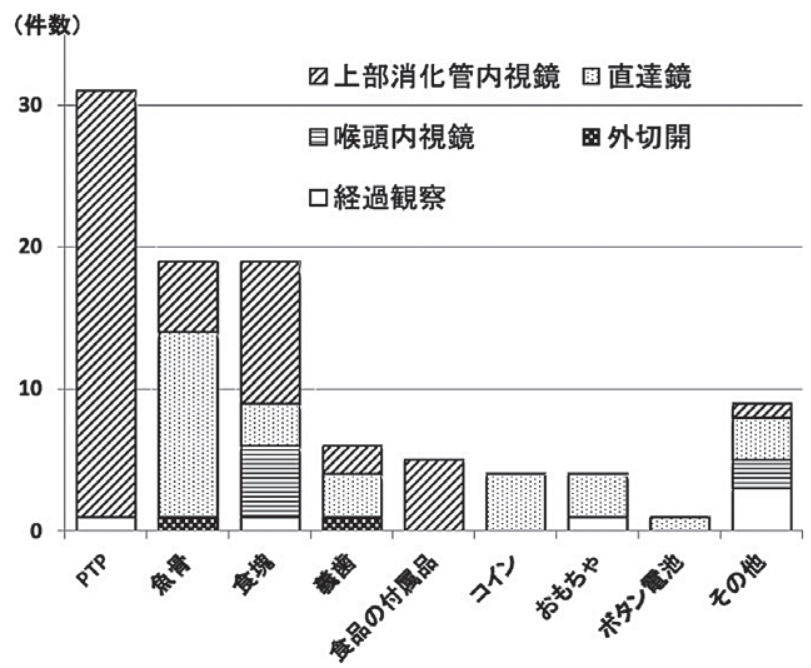

図 4 異物の種類ごと, 摘出方法による分布 PTP は上部消化管内視鏡で，魚骨は直達鏡下での 摘出を中心に施行していた。

食塊については種類・大きさによっては全身麻酔下 での摘出を行っている。
挿入し，異物を胃内に落とす方法も数例で施行され ていた。全身麻酔下で食道直達鏡を用いて摘出術を 施行した症例が 3 例あつたが，いずれの症例も食塊 （肉）に併せて骨を誤飲していた。また義歯・魚骨 異物の摘出に際し, 頸部外切開による異物摘出, 食 道粘膜修復術を要した症例が 1 例ずつ, 計 2 例認め た。問診から異物を疑い上部消化管内視鏡検査を施 行するも，異物が見つからず経過観察となった症例 が 5 例みられた。

全 98 例中，入院加療を要したのは 30 例（約 30\%） であった。30 例中, 全身麻酔下での緊急手術・摘出 術を施行したのが 23 例であった。残りの 7 例は上 部消化管内視鏡での摘出術を施行した後, 粘膜出血 （6 例）や穿孔・Free air の出現を認めた（1 例）為 に入院加療となっていた。手術加療の内訳としては, 食道直達鏡下異物摘出術が 21 例, 頸部外切開によ る異物摘出術が 2 例（義歯異物が 1 例，魚骨が 1 例） であり，魚骨の摘出に際しては甲状腺左葉切除術を 併用した。摘出術後に有害事象・合併症をきたした 症例を 7 例認め, その内訳は咽頭粘膜損傷 4 例, 粘 膜出血 2 例, 細菌性肺炎 1 例であった。入院加療を 要したいずれの症例も, 加療により徐々に軽快し退 院となっている。入院加療を要した症例については, 詳細をフローチャート形式にまとめた（図 5)。

ここで特徵的な症例を 2 例提示する。
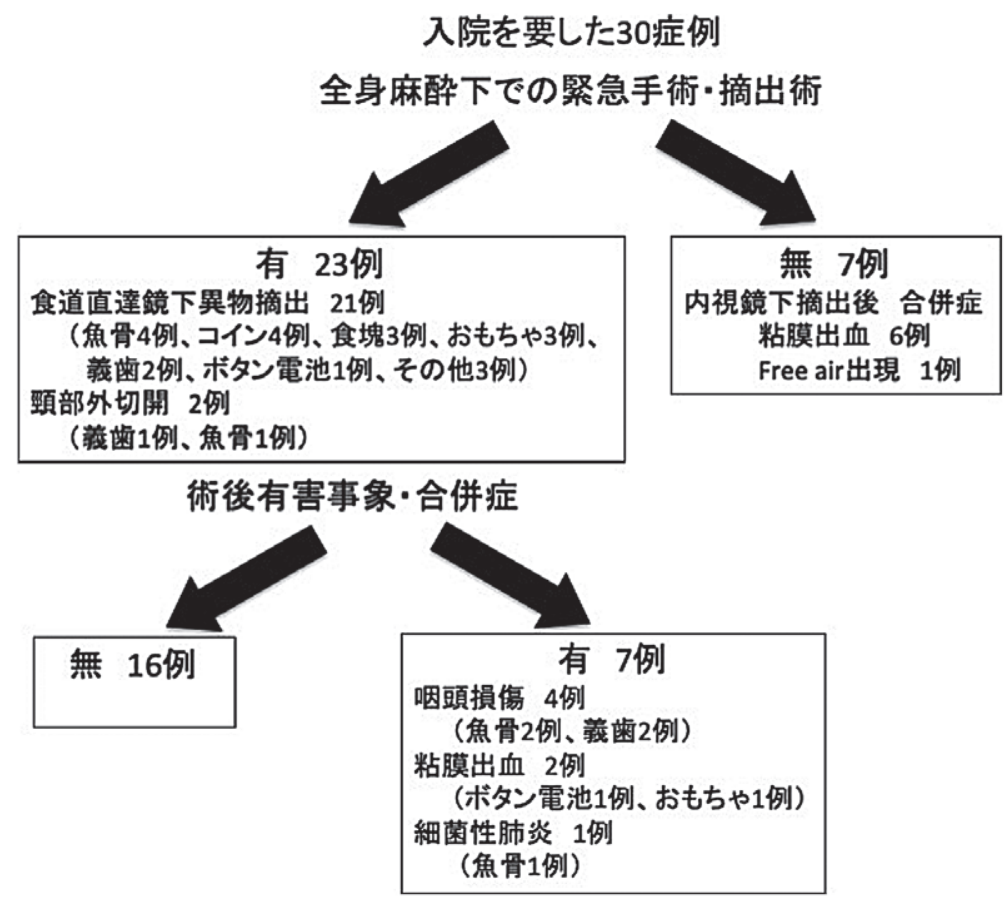

図 5 入院を要した 28 症例の要約（フローチャート形式） 全身麻酔下摘出目的の入院が 21 例で, 内視鏡下摘出後の有害事象 での入院が 7 例であった。

いずれの症例も入院後の治療経過は良好であり, 全症例が軽快退院 となっている。 
【症例 169 歳 女性 PTP 誤飲】

定時内服後に咽頭痛が出現。PTP がひとつ足り ないことに気がつき，PTP 誤飲が疑われ当院救急 外来を受診した。

受診時の胸部 X 線画像と頸部 CT 画像を図に示 す（図 6）。X 線画像（図 6a）では PTP を確認する ことが出来なかったが，CT 画像（図 6b，c）で頸 部食道第一狭窄にPTP と考えられる異物を認めた。

同日緊急で上部消化管内視鏡下で異物摘出術を施 行した。CT 画像所見と同様，食道第一狭窄に異物 を認め，鉗子を用いて異物を把持・摘出した。摘出 に際して特に出血・粘膜穿孔を認めなかったため同 日帰宅とした。その後も有害事象を認めなかったた め, 2 週後に終診とした。

【症例 283 歳 女性 魚骨誤飲】

受診 5 日前から咽頭痛を自覚。咽頭異物を疑い近 医耳鼻咽喉科を受診するも咽頭・喉頭に明らかな異 物は認められず経過観察となった。しかしながらそ の後も咽頭痛が持続したため当科を受診した。

受診時の頸部 CT 画像を図に示す（図 7a, b)。 食道入口部に魚骨を疑う異物を認めるが，その先端 が甲状腺左葉に到達しており，周囲に低吸収域を
伴っていた。受診後の問診で, 咽頭痛出現前に魚を 食していたことが発覚した。魚骨の食道外迷入と診 断し, 全身麻酔下で甲状腺左葉切除術と食道粘膜修 復術を施行するために緊急入院した。

入院同日に緊急手術 (甲状腺左葉切除術, 食道粘 膜修復術）を施行した。甲状腺左葉切除術は通常通 り定型的に施行。甲状腺を翻転させると食道入口 部・輪状軟骨のレベルに貫通した魚骨が見つかり， 慎重に除去した。除去後の食道粘膜は $5 \mathrm{~mm}$ 大の裂 傷となっており, 食道粘膜・甲状咽頭筋を吸収糸で 2 層縫合した。手術終了後は絶飲食管理とした。術 後声帯麻痺や発熱をきたすことなく経過し, 術後 7 日目に食道造影検査を行い咽頭瘦孔がないことを確 認，経口摂取を再開した。経過良好であり術後 10 日目に軽快退院した。

考察

食道異物は耳鼻咽喉科の日常診療において遭遇す る，比較的稀な疾患である。PTPや義歯，おもちゃ など異物誤飲の目撃や証言を参考とし精査を行う症 例から，魚骨や食塊による咽頭痛・違和感など自覚 症状を参考とし精査を行う症例まで多岐にわたる。
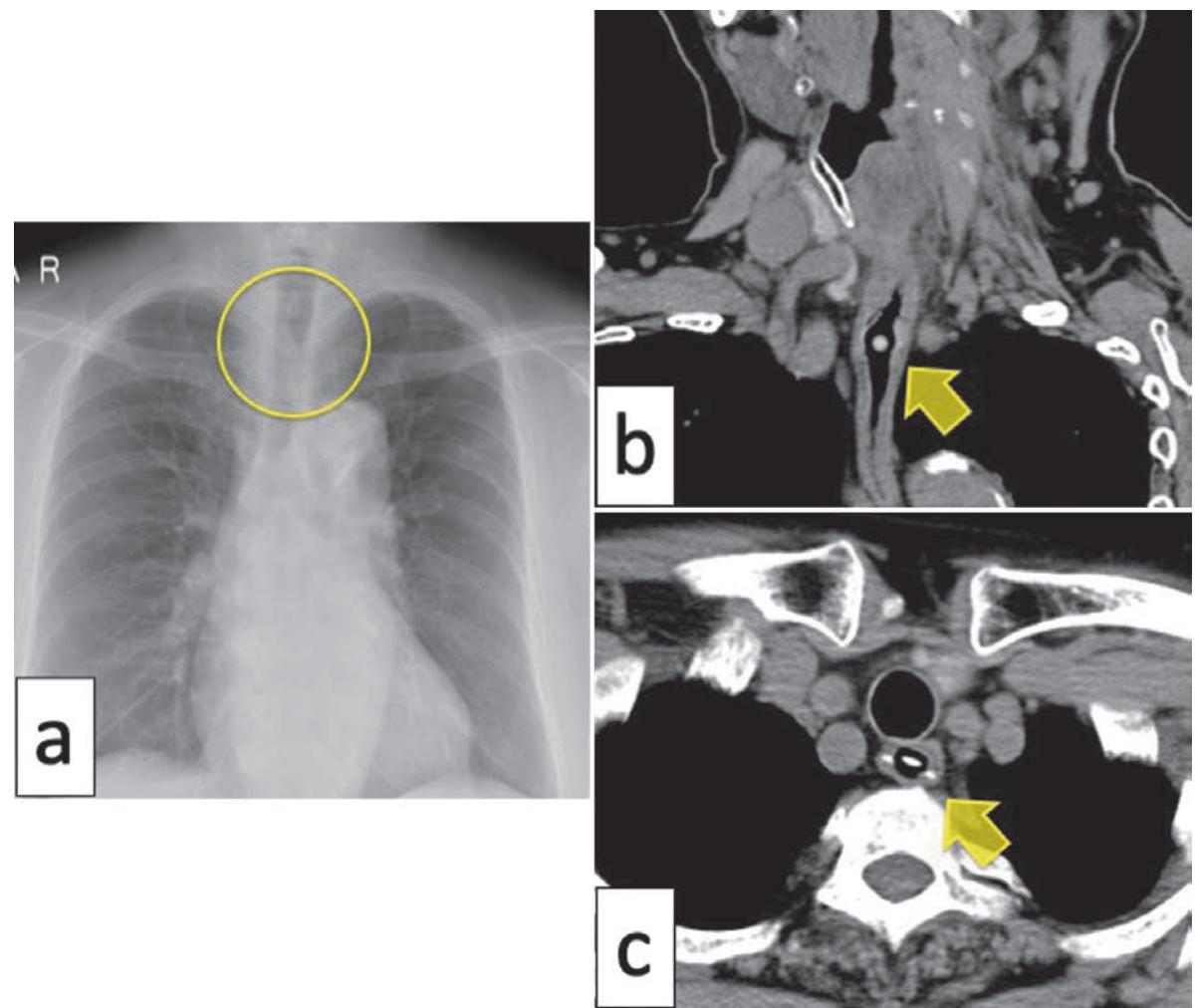

図 6 PTP 誤飲の 1 例 $(\mathrm{a}: \mathrm{X}$ 線画像, b, c : CT 画像 $)$

$\mathrm{a}$ : 胸部 X 線画像。PTP と考えられる異物は認められない。CT 画像で描出され ている部分（円内）にも，明らかな異物は認められない。

$\mathrm{b}$ : 前額断, $\mathrm{c}$ : 冠状断。CT 画像では第 1 狭窄（食道入口部）に錠剤を含んた PTP (矢印) を認める。

このことから，X 線撮影のみで異物の有無を確認することは不適切である。 


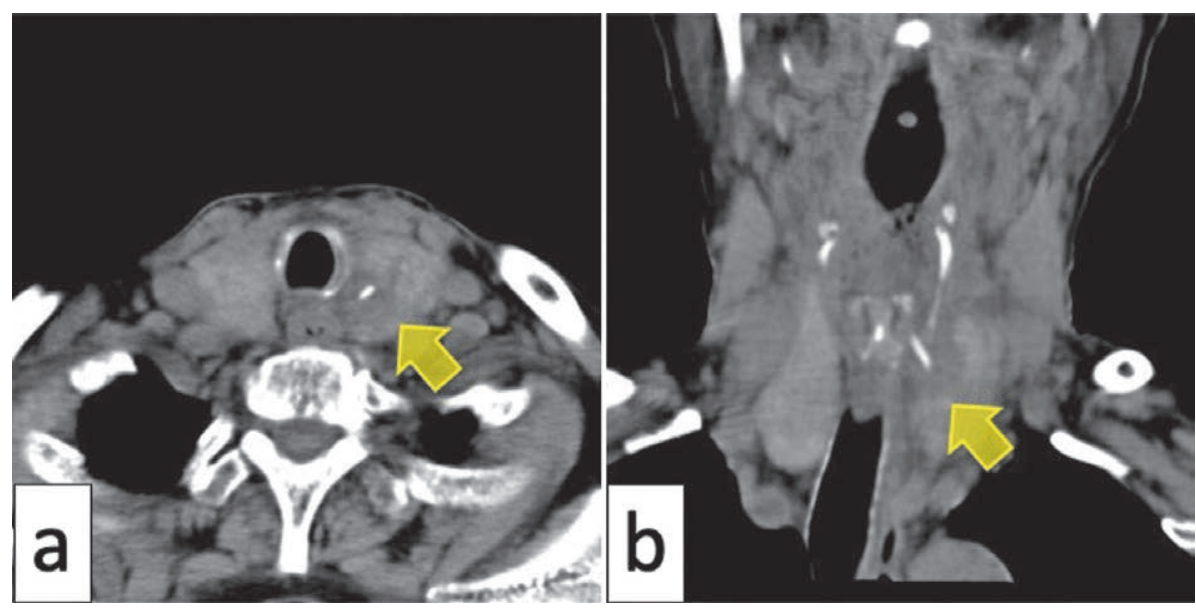

図 7 魚骨異物の 1 例 ( $\mathrm{a}, \mathrm{b}: \mathrm{CT}$ 画像) $\mathrm{a}$ ：冠状断, b : 前額断。咽頭外の甲状腺左葉へ到達する異物（矢印）を認める。 異物の周囲に低吸収域を伴っていた。

表 1 異物摘出術の適応となる異物

\begin{tabular}{ll}
\hline \multirow{2}{*}{ 消化管壁を損傷する可能性があるもの } & 有鈎義歯 (部分入れ歯), 針, PTP 包装された薬剤, 魚骨 (特に \\
& 鯛の骨), 爪楊枝, 鉛筆, ガラス片, 剃刀刃 etc. \\
& 胃石, 食物塊 (肉片など), ビニール袋, 内視鏡的切除術を行った \\
腸閉塞を来す可能性があるもの & 巨大な切除標本 etc. \\
& 乾電池 (マンガン, アルカリ), ボタン電池 (マンガン, アルカ \\
毒性のある内容物を含有するもの & リ, 水銀, リチウム) etc. \\
\hline
\end{tabular}

消化器内視鏡ガイドラインでは，消化管壁を損傷する鋭利な異物，腸閉塞をきたす大きな異物，毒性のある 異物について早急な摘出を要するとされている。

そのため受診患者の年齢分布も幅広くなる。年齢分 布に関しては過去の報告と同様な二峰性の分布で あった ${ }^{1-3)}$ 。厚生労働省の発表によると 2017 年時点 での日本人の平均寿命は男性 80.98 歳, 女性 87.14 歳とされている。女性の割合が多い原因として平均 寿命の差が一因に繋がったと考えられた。

消化器内視鏡ガイドラインの中に, 異物摘出術ガ イドラインという項目がある ${ }^{4)}$ 。その中で異物摘出 術の適応について“そのまま放置すると消化管に対 して重大な影響を及ぼす危険があると判断される場 合”と記載されている。そのような異物として (1)消 化管壁を損傷する可能性があるもの，(2)腸閉塞をき たす可能性があるもの, (3)毒性のある内容物を含有 するもの, の 3 つが挙げられる。特徵的な異物につ いてはガイドラインにもまとめられている（表 1)。 これを参考とし, 緊急性のあるものかどうかを判断 する必要がある。緊急性がある症例に関しては，な るべく早急に摘出術を行うべきである。ただし摘出 術を施行する前に (1)異物の嵌在部位の確認, (2)皮 下・縦隔気腫など合併症確認の為, CT 検査などに よる画像評価を行うべきである。
PTP の材質は金属箔と塩化ビニールであり, 単 純 X 線での描出は困難で診断には至らないため不 適切な検査と考えられている5)。事実, 先に示した 症例 1 では, 単純 X 線正面画像で PTP を指摘する ことは出来なかった。単純 X 線側面画像を追加す ることで，食道入口部に位置するPTP を同定する ことは可能である。しかしながら食道入口部以下に 迷入した異物については胁骨, 椎骨の影響から描出 が困難であり, 単純 X 線のみでは異物の検索・診断 には不適切であると考えられる。一般的な頸部 CT の撮影条件下では錠剂が高信号で描出されるため, それを目安に PTP を検索する必要がある。CT 画像 のスライスと異物の嵌在部位がうまく合致すると, 錠剂と PTP，周囲の空気や食塊などによって 3 層の 異なる density からなる “triple canstasted target sign” ${ }^{6)}$ として描出されることがある。しかし実臨 床においてこのように描出される症例は少ないと考 えられる。今回まとめた PTP 異物 31 例のうち CT 検査を施行している症例は 12 例で, そのうち 4 例 は CT 画像から PTP を確認することはできなかっ た。さらにこの 4 例は上部消化管内視鏡で PTP を 
認め摘出したところ，内部に錠剤が確認できず “錠 剤の内服した後に誤ってPTPのみ誤飲してしまっ た”症例であった。この結果から, 頸部 CT で PTP が描出されないからと言って異物の存在を否定する ことはできず，観察目的の上部消化管内視鏡検查は 必須であるとわれわれは考えている。

PTP や義歯，おもちゃの誤飲のように異物誤飲 の明らかなエピソードがある場合は，問診を参考と して精査・加療を進めていく。しかしながら食事, 特に魚骨による食道異物ではその対応がやや異なる 印象がある。多くの耳鼻咽喉科医は“魚を食べたあ とからの咽頭痛”で受診した患者に対し，まず咽頭 異物を疑い検査を行う。主な方法としては口腔内の 視診，喉頭内視鏡や間接喉頭鏡による咽頭・喉頭の 確認である。そこで異物が認められなければ経過観 察するように指示することが多い。魚骨による食道 異物の場合，耳鼻咽喉科受診後も咽頭痛が持続する ことではじめて食道異物の可能性を示唆され，精 查・加療目的に紹介される症例も一部で見られる。 われわれが経験した魚骨による食道異物 19 例につ いて，受診までの経過や期間について検討した。ま ず当院受診までの経過として，(1)近医からの紹介が 8 例，(2)咽頭痛出現直後に救急外来への受診した症 例が 9 例，(3)近医受診し異物を認めなかったが痛み が持続し受診した症例が 2 例であった。

受診までの期間について，近医からの紹介と救急 外来受診した 17 例はすべて，当日〜異物誤飲後 24 時間以内に受診していた。経過観察後にも痛みが持 続していた 2 例については, 誤飲後 4 日経過した後 に受診していた。この 2 例については披裂の浮腫, 咽頭外への異物迷入を認めたため, 全身麻酔下で摘 出術を施行し, 術後絶食・抗菌薬加療を行い軽快し た。この 2 例の様に経過観察することで状態の悪化 を招くことがある為, 魚骨でも特に硬く大きな骨 （鯛の骨など）による異物を疑う場合は経過観察す べきではない。CT 検査や上部消化管内視鏡検査な どの緊急検查・処置が可能な施設へ，早急な紹介・ 精査が必要と考える。

通常，誤飲された異物のほとんどは数日以内での 自然排泄が期待される。稀ではあるものの, 約 $1 \%$ 程度で消化管穿孔や穿通などの合併症をきたすと報 告されている7,8)。また小腸以下に至った異物，特 に鋭的異物に関しては合併症リスクが $15 〜 35 \%$ と 高率であり，内視鏡的に摘出したほうが良いとされ ている ${ }^{9)}$ 。消化管穿孔・穿通の原因として, PTPゃ 魚骨など鋭利な異物による直接損傷の他，異物の長 期停滞による組織壊死が考えられており ${ }^{10)}$ ，鋭的異 物については自然排泄を期待せず，消化器内科・外
科へ下部消化管の精査について依頼する事も重要と 考えられる。

\section{まとめ}

今回われわれは，過去 11 年間において治療を 行った食道異物 98 例についてまとめた。誤飲のエ ピソードが明らかであれば診断は容易だが，魚骨や 食塊による異物での咽頭痛・咽頭違和感を主訴に来 院された患者に対し，われわれ耳鼻咽喉科医はその 特性から咽頭・喉頭を中心に診療してしまう。喉頭 内視鏡検査で異物が指摘されなければ経過観察で対 応する症例も多いと予測されるが，異物確認の為に 頸部 CT 検査・上部消化管内視鏡検査を行うことは 重要である。また異物が指摘されなくとも誤飲を積 極的に疑う症例，特に PTP・魚骨・義歯など鋭的 異物の誤飲については，下部消化管の精査も必要で あり, 他科（消化器内科・外科）との連携を図るべ きである。

本論文の要旨は第 28 回日本頭頸部外科学会総会（2018 年 1 月 25 日〜 26 日，宇都宮）において発表した。

著者は申告すべき利益相反を有しない。

\section{文献}

1）木村哲郎, 湯田厚司, 篠木 淳, 他：当教室過去 21 年間の食道異物症例の集計。日気食会報, $51: 301-$ 305,2000 .

2）春日井滋, 渡辺昭司, 赤澤吉弘, 他：当教室過去 21 年間の食道異物の臨床統計的観察。日気食会報, $58: 527-532,2007$.

3）能田淳平, 佐伯忠彦, 大河内喜久, 他：口腔咽頭 食道異物例の臨床的検討. 耳鼻喉頭, $86: 1115-1120$, 2014.

4) 日本消化器内視鏡学会監修：消化器内視鏡ガイドラ イン第 3 版, 206-214, 医学書院, 2006.

5）新谷 裕, 木内俊一郎：誤飲したPTP の診断に CT が有用であった 3 症例。日臨救急医会誌，13：664667, 2010.

6）松村博臣, 泉 浩, 土橋洋史, 他 : Press-through package 誤飲による回腸穿孔性腹膜炎の 1 例. 日消 外会誌, $35 ： 317-321,2002$.

7) McPherson RC, Karlon M, Wiliams RD: Foreign body perforation of the intestinal tract. Am J Surg $94: 564-566,1957$.

8) Gracia C, Frey C, Bodai B: Diagnosis and management of ingested foreign bodies. Ann Emerg Med $13: 30-34,1984$

9) Eisen GM, Baron TH, Dominitz JA, et al: Guideline for the management of ingested foreign bodies. Gastrointest Endosc $55:$ 802-806, 2002.

10）藤井研介, 新田敏勝, 川崎浩資, 他 : Press through package 誤飲による S 状結腸穿孔の 1 例. 日本大腸 肛門病会誌, $68 ： 163-167,2015$. 